\title{
Reflective journal writing: How it promotes reflective thinking in clinical nursing education: A students' perspective
}

\author{
J Kok, Final Year BCur Student, Department of Nursing Science, RAU \\ MM Chabeli,PhD, Senior lecturer, Department of Nursing Science, RAU
}

\section{Abstract}

According to the outcomes-based education and training system of education (OBET) in the country and the South African Nursing Council, education should focus on "creating" reflective learners and practitioners. This article seeks to determine the effectiveness of reflective journal writing in promoting the reflective thinking of learners in clinical nursing education and to validate the guidelines described in a bigger study on how to facilitate reflective thinking using reflective journal writing.

A qualitative, contextual, explorative, descriptive research design was used to determine the learners' perceptions on whether reflective journal writing did promote their higherlevel thinking skills during the six-month placement in a psychiatric clinical practice using the reflective diaries. From a population of seventeen fourth-year students, six volunteered to participate in a focus group interview. The data was analysed by means of the descriptive method of open coding of Tesch (in Creswell, 1994:154-156). Positive and negative results from the perceptions of the participants and a literature review served as a basis for deducing and describing guidelines for the effective use of reflective journal writing in promoting reflective thinking in clinical nursing education.

The positive perception was the development of problemsolving skills attained through reflection by using analytical critical thinking, synthesis and the evaluation of situations. Self-evaluation leading to intellectual growth and self-awareness indicated a positive perception. Negative perceptions were that reflective journal writing is time consuming, content based with a lack of clear expectations from the teacher, and distrust of students about the information written. Guba's model of ensuring trustworthiness in qualitative research as described in Krefting (1991:215-222) was employed. It is concluded that reflective journal writing in clinical nursing education does promote reflective thinking and learning. The use of the developed guidelines will minimise the negative perceptions. It is recommended that the guidelines be used in basic training at all levels of training to attain the objective of nursing education and training, which is to produce a critical, analytical thinker through reflection to improve practice.

\section{Opsomming}

$\mathrm{Na}$ aanleiding van die stelsel van uitkomsgebaseerdeonderrig (UGO) in die land en van die Suid-Afrikaanse Raad op Verpleegkunde, behoort onderrig te fokus op die "skepping" van reflektiewe leerders en praktisyns. Hierdie artikel poog om die doeltreffendheid van reflektiewe dagboekskrywing te bepaal ter bevordering van reflektiewe denke by leerders in kliniese verpleekunde en om die riglyne wat beskryf is in " $n$ groter studie oor hoe reflektiewe denke deur die gebruik van reflektiewe dagboekskrywing fasiliteer moet word, te staaf. 'n Kwalitatiewe, kontekstuele, ondersoekende en beskrywende navorsingsontwerp is aangewend om die leerders se persepsies te bepaal ten opsigte daarvan of reflektiewe dagboekskrywing hul hoervlak denkvaardighede bevorder het deur die gebruik van reflektiewe dagboeke, gedurende hul ses maande plasing in psigiatriese kliniese praktyk. Ses studente uit 'n populasie van sewentien vierdjaar studente het vrywillig in ' $n$ fokusgroep-onderhoud deelgeneem. Data is deur middel van die beskrywende metode van opekodering van Tesch (in Creswell, 1994:154-156) ontleed. Beide positiewe en negatiewe resultate van die persepsies van die deelnemers en literatuurstudie het as basis gedien vir die deduksie en beskrywing van riglyne vir die doeltreffende gebruik van reflektiewe dagboekskrywing ter bevordering van reflektiewe denke in kliniese verpleegkunde. Positiewe persepsie was die ontwikkeling van probleemoplossingsvaardighede wat bereik is deur refleksie deur die aanwending van analitiese kritiese denke, sintese en die evaluering van situasies. Selfevaluering wat lei tot intellektuele groei en selfgewaarwording, het positiewe persepsie aangedui. Negatiewe persepsies was dat reflektiewe dagboekskrywing tydrowend en inhoudgebaseer is, met gebrek aan duidelike verwagtinge van die leerkrag en wantroue onder studente oor die inligting wat geskryf is. Guba se model vir die versekering van betroubaardheid in kwalitatiewe navorsing, soos beskryf in Krefting (1991:215-222), is aangewend. Daar is tot die gevolgtrekking gekom dat reflektiewe dagboekskrywing in kliniese verpleegkunde wel reflekteiwe denke en leer bevorder. Die gebruik van die ontwikkelde riglyne sal negatiewe persepsies minimaliseer. Daar word aanbeveel dat die riglyne gebruik word tydens basiese opleiding op alle vlakke van opleiding om die doelwit van verpleegkunde en opleiding te gebruik d.w.s om, deur refleksie, 'n kritiese, analitiese denker voort te bring, sodat praktyk verbeter kan word. 


\section{Background and rationale}

Thinking skills develop as students make explicit their ways of thinking, hear alternative ways of thinking, and reflect on their thinking. According to Costa (1991:12), the focus of a teacher's attention should not be on teaching students to think in a particular way, but on helping them explore and reflect on the thinking processes they already use. As teachers, he stated, our challenge is to understand the way students are making sense of things, the logic they are using, and the sources of information they are drawing upon. There are numerous ways in which we can create an atmosphere that allows students to reflect on their own thinking and promote reflective learning, and reflective journal writing is one of them.

Reflective learning, according to Boyd \& Fales (1983:100), is the process of internally examining and exploring an issue of concern, triggered by an experience, which creates and clarifies meaning in terms of the self, and which results in a changed conceptual perspective. Reflective learning is the key element in learning from experience. Reflective learning places the emphasis on the self as the source of learning and is inherently an individual and interactive process.

According to Wong; Kember; Chung \& Yan (1995:50) reflective journal writing involves a reflective process that is initiated when the learner documents the experience encountered, returns to the experience, recollects what has taken place and replays the experience, and re-evaluation takes place. Wong et al (1995:53) view the process of re-evaluation as involving association (relating new information to that which is already known), integration (seeking relationships among the data), validation (determining the authenticity of the ideas and feelings that have resulted) and appropriation, which entails making knowledge one's own.

From the explanations of reflective learning and reflective journal writing, it becomes clear that the underlying dynamic of reflective journal writing is interaction. This is in line with the expectations of outcomes-based education and training. Central to OBET is reflective learning, in which the emphasis no longer falls on memorising factual knowledge, but on collaborative interaction to develop reflective thinking skills and learning in clinical nursing education to improve practice and develop lifelong learning skills. The emphasis falls on embedding quality problem-solving skills rather than on memorising a given amount of scientific information. The teaching and evaluation methods at all levels and in all programmes of education and training should encourage reflective and critical thinking, the ability to ask thought-provoking questions, to stimulate an enquiring mind, to develop reasoning skills, to communicate effectively and to form judgements (Pretorius, 1998:3,5).

The South African Nursing Council policy on nursing education (1993:6) states that the purpose of nursing education programmes should be the development of the learners' ability regarding analytical, critical, evaluative and creative thinking and the continuing stimulation of the learners' capacity to interpret scientific data for nursing actions, to draw conclusions and to exercise independent judgement. They expect nurse who can practise independently and take responsibility for their actions; nurses who can evaluate themselves and who can develop themselves personally and professionally; and who can question and approach problems scientifically for the purpose of effective practice. Thus, professional education should aim at preparing professionals who can ultimately apply theoretical knowledge to practice in the real world (Wong et al 1995:48).

From literature, we learn that reflective journal writing is one of the learner-centred teaching strategies that can promote the learner's critical and reflective thinking (Rolfe; Freshwater \& Melanie, 2001:23; Costa \& Lowery, 1989:90; Wong et al, 1995:53 and Chabeli, 2001:269). Final-year students following a comprehensive four-year degree leading to registration with the SANC as a nurse (general, psychiatric and community) and midwife where expected to use reflective diaries to enter their daily experiences in a psychiatric unit were they were placed for six months for their clinical practice. Students were given guidelines on how to use reflective journal writing as a teaching strategy to gain clinical knowledge. They were expected to submit the dairies at the end of the six- month period for evaluation. In spite of the guidelines, the perceptions of the students who participated in the study indicated that the students did not use the strategy appropriately. Many students completed their journals only the night before they had to be submitted. They had to remember most of what had happened over six months in one night.

Some journals were only summaries of what had happened every day or every week with no details. As a result, the objective of the exercise was not met by some students. Hence, the purpose of this article is to describe the guidelines to improve the implementation of reflective journal writing as a teaching strategy to promote reflective thinking in clinical nursing education in order to have what Shields (1995:452) refers to as "knowledgeable doers".

\section{Problem statement and research question}

Shields (1995: 425) is of the opinion that clinical practice needs "knowledgeable doers". It is therefore imperative that teachers focus on using learner-centred teaching strategies that are learner friendly, such as reflective journal writing to promote reflective thinking and learning to improve practice. However, from the perceptions of the students who participated in the study, it appears that some student nurses in question did not use this method (reflective journal writing) to promote thinking skills properly, as evidenced by:

- Only completing the diary the night before the sub mission date.

- Only factual content or summaries of what had happened were written.

- They were not motivated to do it - they only did it to obtain examination marks.

The following research questions emerged from the problem statement: 1 . What is your perception with regard to the use of reflective journal writing to promote reflective thinking in 
clinical nursing education? 2. How can the use of reflective journal writing promote reflective thinking in clinical nursing education?

\section{The objectives of the study}

The objectives of the study are as follows:

- To explore and describe the perceptions of learners regarding the use of reflective journal writing to promote reflective thinking skills in clinical nursing education.

- To describe guidelines on how to effectively use reflective journal writing to promote the learner's reflective thinking skills in clinical nursing education.

\section{Definitions of central concepts Reflection}

Reflection is the process of creating and clarifying the meaning of experience (present or past) in terms of the self (the self in relation to the self, and the self in relation to the world). The outcome of the process is a changed conceptual perspective (Boyd \& Fales: 1983: 111,112).

\section{Reflective learning}

Reflective learning, according to Boyd \& Fales (1983:110), is the process of internally examining and exploring an issue of concern, triggered by an experience, which creates and clarifies meaning in terms of the self, and which results in a changed conceptual perspective. Reflective learning is the key element in learning from experience. Reflective learning emphasises the self as the source of learning and is, therefore, inherently an individual and interactive process.

\section{Reflective journal writing}

Reflective journal writing is a teaching strategy whereby students write their experiences and feelings 'uncensured' in their own writing style for further reflection and analysis (Heath, 1998:593) The reflective journal is used by both the educator and the student in the clinical setting to learn and assess the progress of the learner towards acquiring the skills of self-directed learning. This method of teaching invites the student to be creative in identifying personal learning needs and designing learning experiences (Stark in Riley-Doucet \& Wilson 1997:965-966). The learners thus select aspects of a clinical experience that are noteworthy or meaningful to them and write them down in diaries (Boykin \& Schoenhof in Paterson 1995:211).

\section{Reflective thinking}

Reflective thinking is a rational, reasonable thinking implemented by mental discipline. During a reflective activity one turns one's thought back upon an existing idea of knowledge that may have taken to be some degree dependable (Biggae \& Shermis 1992:276). Reflective thinking employs thinking skills such as analysis, synthesis and evaluation to reach a conceptual change (Atkins \& Murphy, 1993:1190).

\section{Clinical context}

The clinical context is a dynamic, multipurpose real-life environment that is constantly changing, in which theoretical knowledge is integrated with practice. It provides the learner with a meaningful, authentic and humane experience (Chabeli 2001:150).

\section{Learner}

In this study, the learner will refer to the final year BCur (bachelor's degree in nursing science) student at a university in Gauteng. On completion of the four- year comprehensive course, the student will be able to register with the South African Nursing Council (SANC) as a nurse (general, psychiatric and community) and midwife.

\section{Research design and method}

A qualitative, contextual, explorative and descriptive research design was used (Mouton \& Marais, 1994:43-44) where the results of the focus group interview controlled by literature served as a basis for the description of the guidelines for the effective implementation of reflective journal writing in clinical nursing education to promote reflective thinking.

\section{Research Method}

The research method constitutes the population, sample and sampling, data collection method and data analysis (Burns \& Grove, 1993:578-579). From a population of seventeen fourthyear students undergoing a four-year comprehensive course, six students volunteered to participate in a focus group interview Morgan \& Krueger (1998:29-35) to explore and describe their perceptions with regard to the use of reflective journal writing as a teaching strategy to promote reflective thinking. The six students gave a written consent, and their confidentiality and anonymity were ensured. The group was placed in a psychiatric institution for six months to gain their clinical knowledge and skills. They were given guidelines to use reflective journals to write their experiences and to submit the diaries at the end of their six months clinical placement.

The author of this article was one of the group members. She decided to conduct the study on the effectiveness of reflective journal writing in promoting reflective thinking among her peers with the aim of describing guidelines to improve its implementation in future as part of the requirement for the research project. The author did not take part in the focus group interview, but collected the field notes as the interviewer, who was purposively selected because of his expert interviewing skills, conducted the interview.

This method allowed members of the group to describe their perceptions about reflective journal writing as a teaching strategy to promote thinking skills freely and allowed group interaction to generate ideas on how reflective journal writing should be used to facilitate reflective thinking. The interview was conducted in Afrikaans, as all the participants were Afrikaans speaking. The data was later translated to English. Two questions were asked during the focus group session: What are your perceptions regarding the use of reflective jour- 
nal writing to promote reflective thinking skills in clinical nursing education? How can the use of reflective journal writing promote reflective thinking in clinical nursing education? A tape recording was used with their permission.

The participants were asked not to use their names for the sake of confidentiality. This formed part of the ground rules that were established by the participants and the interviewer. The interviewer used probing, follow-up questions, openended questions, unplanned and serendipitous questions, nodding, minimal verbal responses, and encouraged the less active participants while conducting the interview. The interviewer continued with the interview until saturation of data was reached. The researcher took comprehensive field notes, noting the participants' group dynamics, such as verbal and non-verbal communication, key issues, facts and opinions, feelings and emotions. The entire focus group lasted approximately one hour.

Data was analysed by means of the descriptive method of open coding as described by Tesch (in Creswell, 1994:154-156) by the researcher and the independent coder who was purposively selected on the basis of her knowledge of psychiatry and quali- engagement over a period of six months involved with writing reflective journals to integrate theory with practice, keeping reflexive field notes, member checking through a literature control by using findings of similar studies on reflective journal writing. Triangulation of sources added to the credibility of the study.

Dependability was achieved through a dense description of the data, audit trail and use of a co-encoder in the data analysis process by using Tesch's protocol. Transferability was ensured by a sample from volunteered students, dense description of the method and a literature control. Confirmability was ensured by an audit trail and reflexivity (Krefting, 1991:215-222).

\section{Findings and discussion of the findings}

Table 1 provides an overview of the major themes and subthemes of the perceptions of the participants with regard to the use of reflective journal writing to promote reflective think-

\section{Table 1: An overview of major themes and sub-themes of perceptions with regard to the use of reflective journal writing to promote reflective thinking skills in clinical nursing education}

\begin{tabular}{|l|l|}
\hline Positive Perceptions & Negative Perceptions \\
\hline Sub-themes: & Sub-themes: \\
$\begin{array}{ll}\text { 1. Problem-solving skills to integrate } \\
\text { theory and practice. }\end{array}$ & $\begin{array}{l}\text { 1. Time consuming } \\
\text { Reflection through: }\end{array}$ \\
$\begin{array}{l}\text { Critical and analytical thinking skills } \\
\text { - Synthesis }\end{array}$ & 3. Is content based \\
- Evaluation & \\
2. Self-evaluation, intellectual growth & \\
and self-awareness & \\
\hline
\end{tabular}

tative research to ensure the trustworthiness of the categories.

\section{Measures to ensure trustworthiness}

Guba's model (in Krefting, 1991: 215-222) for ensuring trustworthiness based on the suggested strategies of credibility, transferability, dependability and confirmability was used. Credibility was ensured through the researcher's prolonged ing in clinical nursing education. Two major themes were identified as positive and negative perceptions with regard to reflective journal writing in clinical nursing education. The main positive sub-theme was that reflective journal writing promotes problem-solving skills through reflection by using critical, analytical thinking skills, synthesis and evaluation. The second one is self-evaluation, intellectual growth and selfawareness. The learners are able to integrate theory with practice. The negative sub-themes were that reflective journal writing is time consuming, and content based, the expectations from the students are not clear and there is a lack of 
trust. Direct quotes from the participants will be provided in italics.

\section{Positive perceptions Problem-solving skills}

The participants were of the opinion that reflective journal writing facilitates their problem-solving skills in integrating theory with practice as evidenced by: "I feel the writing of a reflective journal is important and it works" The participants further stated: "You think more critically about certain things and you analyse them"; "It is a type of cognitive stimulation": It gives you guidelines for when you are in a similar situation again"; You reflect on it and try to solve the problem. But problem solving requires reasoning, so we can develop our reasoning by discussing with our fellow students. We have to engage in arguments to justify our standpoint, which we can only do after the incident with the teacher present"; "It definitely improves your thinking skills, because you think about it on a higher level".

Costa (1991:3) maintains that further development and emphasis is needed in teaching skills of problem solving, reasoning, conceptualisation, analysis, synthesis and evaluation, which are among the neglected basics needed in tomorrow's society. "When you synthesise; you build knowledge in a different way"; "It is something like Aha! You develop new' insight as you perceive the situation differently, based on a previous conception"; "You have more practical skills that you can relate to theory" and "You can evaluate yourself in this way". Many scholars in nursing see reflective journal writing as a means of bringing nursing theory and practice together through praxis (reflection and action). It is seen as a most viable means by which self-understanding and nursing knowledge are increased (Gray \& Pratt in Graham. 1995:29).

Costa, $(1991: 4,5)$ believes that reflective journal writing increases the opportunity for problem solving during the verbal interaction of experiences between the teacher and student peers. Students develop listening skills, co-operative learning, thought-provoking enquiring discussion, dialogical reasoning and brain- storming abilities. Costa (1991:27) further states that to process data acquired or observed into meaningful relationship, the student must be drawn to the higherorder thought processes, such as critical analyses, synthesis and evaluation.

The teacher must provide an enabling and a motivating environment of support and guidance that is non-judgemental, an environment in which a student can verbalise innovative ideas that she/he has experienced by using all the senses, the main purpose being to develop their intellect. Costa (1991:5) places more emphasis on more time spent on dialectic discussion immediately after the experience is written in the diary to facilitate student growth in reflective thinking.

The use of reflective journal writing has been widely reported in nursing literature as an effective strategy for assisting students to reflect about learning experiences in the clinical area (Paterson, 1995:211). The central point of reflection in learning is experience (Reid, in Wong et al 1995:49). Experience alone is, however, not the key to learning. Learning from experience involves reflection (Wong et al, 1995). The cognitive activities include making inferences, discriminating and associating relationships, and validating assumptions. Reflection generally involves higher-order mental processes at the conscious level Mezirow et al (in Wong et al 1995:49), which should be used in the discussion period of reflective journal writing.

\section{- Self-evaluation, intellectual growth and self-awareness}

Many learners thought that reflective journal writing had value for themselves and that it could be useful in self-evaluation, intellectual growth and self-awareness, as indicated: "It is personal; it is about your personal intellectual growth, overcoming your own problems"; "At the end of the da,y I benefit from it... it makes me grow intellectually and personally"; "I also think it makes you more mature and it helps you to handle a situation more professionally...".

"Self-assessment plays an integral part in the facilitation of reflective thinking because it forces the learners to reflect back on their thoughts and actions. It is important for selfregulated learning since it promotes the learner's sense of ownership and responsibility", stated the participants. "When you reflect back on your reflective journal, you feel good that you were able to write your experience and feelings. Whether it is the correct information or not, that will be clarified by the teacher and other students during the discussion session".

The progressive skills of self-reflection and critical thinking are fundamental to the development of the self-directed learning process (Newell in Riley-Doucet \& Wilson, 1997:964965). "We develop analytical critical thinking skills as we debate and argue situations in an effort to connect and relate different experiences by different students. When we justify our thinking, we verbalise our thinking loudly, and fellow students can criticise you and thus growth in thinking develops".

Self-awareness means having a deep understanding of one's emotions, strengths and weaknesses, because individuals have the ability to stand back and look at themselves. However, the issue is not so much about whether we have the ability to understand ourselves, but rather how we use the information available to us to reflect on our actions (Palmer; Burns \& Bulman, 1994:102).

Walker (in Shields 1995:453) states that students are visited by their own moral dilemmas in the course of their work and they have to resolve them in a way that they find satisfying in a free and supporting environment. The resultant learning will be of a personal nature and will not be easily predicted. Self-directed learning promotes proactive rather than reactive thought and reactions, and leads to greater personal and professional self-awareness of growth and development. It can be concluded that reflective journal writing should promote reflective thinking skills which will be used for the integration of theory and practice, to develop sound problem-solving skills by using the process of reflection through the em- 
ployment of critical and analytical thinking skills, synthesis and evaluation.

It can also be inferred that reflective journal writing, when used correctly, should lead to self-evaluation, intellectual growth and self-awareness. Riley-Doucet \& Wilson (1997:965966) describe the three-step method of self-reflection using reflective journal writing encompassing the critical appraisal phase, peer group discussion and the self-awareness phase. The guidelines for employing reflective journal writing will be described fully by using the empirical data controlled by literature using the three phases as described by (Riley-Doucet \& Wilson 1997:965-966).

\section{Negative perceptions}

\section{- Time Consuming}

Two of the participants were of the opinion that: "It was a big waste of time... I have better things to do than to write a journal"; "At the end, we felt we didn't want to make time for it". For learners to appreciate reflective journal writing, the allocation of sufficient time and space for reflecting on experiences is important and would enhance the reflective process according to (Boud et al in Wong et al 1995:50).

It seems reasonable to hold that writing immediately after the experience can help a student capitalise on the experience of having been in the situation. It helps the student to differentiate between what she/he thinks happened and what really happened, because the student "revisits" the experience later while the experience is still freshly remembered to be discussed at the end of the working shift. However, if the student depends on memory, potential learning is likely to be lost (Shields, 1995:453).

\section{- Lack of clear expectations}

Some participants experienced negative feelings towards writing reflective journals, because they did not have a clear picture of the goals, objectives or their expectations regarding reflective journal writing. Furthermore, they felt that they did not have a choice in the situation and it had no meaning to them, as stated: "I didn't have any need to complete it"; "I only wrote it because we had to hand it in"; "I experienced it as a schlep..."; "It is an effort to fill it in"; "I looked at it and realised that I didn't understand... I don't think they ever explained to us exactly how to do it, I had no clue...".

In a study on reflective journal writing conducted by Cameron \& Mitchell; Carswell \& Fulwiler ( in Paterson, 1995:211), it is stated that not all students responded positively to journal writing as a learning tool. Some students complained bitterly about the requirements that they write and submit weekly journals to their teachers. Others begin by writing enthusiastically in their clinical journal, but after several weeks, they become noticeably indifferent to the activity (Cassidy \& Luxton in Paterson. 1995:211). Some students regard journal writing as "busy work", unworthy of attention or effort usually reserved for examinations and academic papers (Blough \&
Berman in Paterson. 1995:211). The negative feelings of students concerning the use of reflective journal writing may be overcome by the effective use of the strategy using the described guidelines.

The reflective process involves both feelings and cognition, which are closely interrelated and interactive. The feelings may be positive or negative. Intensive personal feelings are also present towards the end stage of the reflective process (Mezirow et al in Wong et al 1995). It is therefore imperative that, for learning and thinking skills to be promoted, teachers should explain the purpose of the journals with clear instructions in a language the learners can understand and set expectations for both the teacher and the learners. This can be practised in class before the actual experience in the clinical setting. By doing this the learners are likely to feel positive and confident about the writing of the journals.

\section{- It is content based}

Some of the participants were of the opinion that "not one of our journals are about deeper emotions. It is all superficial stuff"; "I wrote: today we were here... this happened, this happened, that happened... and really no deep reflection. At the extreme, some students never seem to have understood what was expected in journal writing". Such students produce mere itineraries of their clinical day, void of reflection and personal insights, state (Holland in Paterson. 1995:212).

The researcher's interpretation of this situation is that when learners do not understand the purpose and process of reflective journal writing, the reflective journal only becomes a diary of events and not a journal in which to reflect and from which to learn. This can be addressed by explaining the process and purpose of reflective journals and giving examples of reflective entries from previous years for learners to understand what is expected from them. Another way is to conduct debriefing sessions and give continuous support, guidance and feedback. The learners will feel at ease to write what they feel if they know that it will be dealt with in a non-intimidating environment. It will also help if they know it will not affect their examination marks, that the content will not be used against them, especially their emotions and there will be no discrimination against them because of what they wrote.

\section{- Distrust}

One participant said: "I don't want to write down my emotions for others to read... I don't know how the people would interpret it"; "I didn't know who was going to read it"; "I felt I was going to harm myself if I wrote what emotions went through me...". Saylor (in Riley-Doucet \& Wilson 1997:965) states that the concept of a safe learning environment is identified as essential to learning the skill of reflection. A safe environment is one in which the students are free to examine and reflect on their work with patients thoughtfully and honestly, without fear of judgement or reprisal. There should be trust, respect for and support and an empathetic understanding of the students' ef- 
forts. Reflective journal writing is described as being student friendly Ishida et al (in Riley-Doucet \& Wilson, 1997:965) and it should establish a co-operative, educator-student relationship built on a model of mentorship (McAlpine in RileyDoucet \& Wilson, 1997:965).

It is therefore concluded that reflective learning and thinking can take place only in an environment that is conducive to thinking and learning. Such an environment can be created by keeping the journals anonymous and confidential; building a relationship of trust before requesting a reflective journal to be written and informing the learners on who is going to read the journal. The learners should develop a sense of trust, independence and ownership of their learning.

\section{Description of guidelines for the effective use of reflective journal writing to promote reflective thinking}

As indicated in the text, guidelines will now be described according to the identified perceptions by the participants and supported by literature. The guidelines will be described within the framework of Reilly-Doucet \& Wilson, (1997:965-966) in three phases (critical appraisal, peer group discussion, selfawareness and self-evaluation).

\section{Critical appraisal}

- The teacher should explain the purpose of the journal with clear expectations in a language that the learners will understand. Set expectations for both the teacher and the learner.

- $\quad$ The teacher should give the learners guidelines and a good example of a reflective journal entry from previous groups just to give them insight into what is expected from them. A scenario can be developed and role-played for more clarity on the expectations.

- The teacher should conduct a briefing session with the learners to make them feel comfortable in using the strategy. Explain that they are given freedom to include descriptions, emotional reactions and cathartic reflections of their experiences. Their knowledge and feelings will be respected.

- Learners should be allowed to use their own individual writing styles.

- There must be no refinement for an academic format.

- Emphasis is placed on writing for the sake of the learner's own intellectual growth. "Write your thoughts, feelings and emotions according to your interpretation of the situation".

- The teacher should allow adequate time and space for the learners to complete the journal entries immediately after they have experienced the learning event or activity, which will be discussed later at the end of the working shift.

\section{Peer group discussion}

The purpose of this phase is to enhance reflective learning by strengthening the link between the learning experience and the reflective activity through dialogic discussion.

- The teacher should explain to the learners what is expected in this stage of peer group discussion.

- The teacher should provide a supportive climate for the discussion, a climate of trust, respect and empathetic understanding.

- Allow the learners to discuss the practical and realistic aspects of their experiences freely.

- Stimulate the learners' cognitive activities by allowing them to make their own interpretations and inferences. Discriminate and distinguish what has happened with what was supposed to happen. Make associations of relationships and validate assumptions.

- These reflective processes will be made possible by encouraging dialogue, discourse and argumentation to justify their opinions in a rational manner.

- The teacher should act as a resource person encouraging the learners to express their views and to help with the integration of a theoretical perspective with their experience.

- The teacher must be available for student guidance and support at all times

\section{Self-awareness to self-evaluation}

This phase concludes the process of reflective journal writing. The learners undertake a self-assessment and evaluation of their experience and consider the experience from a different dimension, that is, they adopt a holistic approach to the learning experience.

- After the discussion, the teacher should allow the learners to complete their reflective journals meaningfully and independently.

- The learners are expected to document aspects of their own learning as an outcome of group discussion. They use subject-related references, their textbooks, subject experts and documents in the unit to analyse clinical incidents in relation to their own learning. This provides a higher-order reflection by the learners as they engage in the dynamics of self-reflections and acquire the skills of self-evaluation.

- The learners use the written document for the final evaluation and measure their progress in meeting the expected clinical learning outcomes of a specific content.

- The facilitator and peers provide a positive and constructive feedback from their knowledge and perspective to add value to the experience.

- Reflective journals should be learner friendly. Learners should feel free to examine and reflect on their experiences thoughtfully and honestly without fear of judgement or reprisal by the teacher.

- $\quad$ Reassure learners that what they have written will not be used against them. They will not be discriminated against because of what they have written.

- The content of the reflective journals will be kept con- 
fidential by the teacher. Learners should have hope and a sense of trust and ownership of their work.

\section{Limitations of the study}

The entire population did not participate in the focus group, other themes that could have emerged. The population constituted only six students at one university in Gauteng, which makes the generalisation of the findings difficult. The researcher experienced a lack of time to spend on the research, as she also had other subjects and practical work to do during the research period.

\section{Recommendations}

The researcher recommends that this study be replicated at other universities and on learners of different year groups to determine the effectiveness of reflective journal writing in promoting reflective thinking in clinical nursing education, and that the guidelines be implemented in order to have knowledgeable and reflective practitioners.

\section{Conclusion}

This study has a significant contribution in nursing education. The researcher has described the perceptions of finalyear nursing students on the use of reflective journal writing in promoting reflective thinking skills in clinical nursing education. A literature review to control the findings was used. Guidelines on how this teaching strategy could be implemented to promote the learner's reflective thinking are described. Teachers and students should reach out to assure quality education by using varied learner-centred teaching strategies such as portfolios that could facilitate reflective thinking and consequently improve practice. The time has come to stop the lip-service and to promote action. More of the evidence-based guidelines of other reflective teaching strategies are welcomed in nursing education.

\section{References}

ATKINS, S \& MURPHY, K 1993: Reflections: A review of the literature.. Journal of Advanced Nursing. 18: 1188-1192.

BIGGAE, ML \& SHERMIS, SS 1992: Learning theories for teachers. New York: Harper Collins Publishers Inc.

BOYD, EM \& FALES, AW. 1983: Reflective learning: Key to learning from experience. Journal of Humanistic Psvcholgey. 23(2): 99-117.

BURNS, N \& GROVE, SK 1993: The practice of nursing research conduct, critique and utilization. Toronto: WB Saunders Company.

CHABELI, M 2001: A Model to facilitate reflective thinking in clinical nursing education. Johannesburg: Rand Afrikaans University (D-Cur Thesis).

CRESWELL, JW 1994: Research Design: Qualitative and Quantitative Approaches. New Delhi: SAGE Publications.
COSTA, AL 1991: Developing minds. A resource book for teaching thinking. Revised edition, volume 1. Virginia: Association for supervision and curriculum development.

COSTA, AL \& LOWERY, LE 1989: Techniques for teaching thinking. United State of America: Critical Thinking Press \& Software.

GRAHAM, IW 1995: Reflective practice: using the action learning group mechanism. Nurse Education Todav. 15: 2832.

HEATH, H 1998: Keeping a reflective practice diary: A practical guide. Nurse Education Today. 18:592-598.

KREFTING, L 1991: Rigor in Qualitative Research: The Assessment of Trustworthiness. The American Journal of Occupational Therapy. 45(3):214-222.

MORGAN, DL \& KRUEGER, RA 1998: The Focus Group Kit. Volume 1-6. California: SAGE Publications.

MOUTON, J \& MARAIS, HC 1994: Basic concepts in the methodology of the social science. Pretoria: HSRC Publishers.

PALMER, AM; BURNS, S \& BULMAN, C 1994: Reflective practice in nursing. The growth of the professional practitioner. London: Blackwell Scientific Publications.

PATERSON, BL 1995: Developing and maintaining reflection in Clinical Journals. Nurse Education Todav. 15:211220.

PRETORIUS, F 1998: Outcomes-Based Education in South Africa: Policy and Concepts; Implementation; Management; Quality Assurance. Western Cape: National Book Printers.

RILEY-DOUCET, C \& WILSON, S 1997: A Three-step method of self-reflection using reflective journal writing. Journal of Advanced Nursing. 25:964- 968.

ROLFE, G; FRESHWATER, D \& MELANIE, J 2001: Critical reflection for nursing and the helping professions, a user's guide. New York: Palgrave.

SOUTH AFRICAN NURSING COUNCIL 1993: Policy regarding nursing education. Pretoria

SHIELDS, E 1995: Reflection and learning in student nurses. Nurse Education Today. 15:452-458.

WONG, FKY; KEMBER, D; CHUNG, LYF \& YAN, L 1995: Assessing the level of student reflection from reflective journals. Journal of Advanced Nursing. 22: 48-57. 